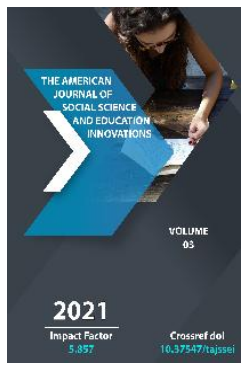

Journal Website: http://theamericanjour nals.com/index.php/taj ssei

Copyright: Original content from this work may be used under the terms of the creative commons attributes 4.0 licence.

\section{Modern Technology And Competence In Dispute Management And Resolution (In The Context Of Mediationtion In Family)}

Mohira Xoliqova

Republic Of Uzbekistan Ministry Of Neighborhood And Family Support Research Institute "Mahalla And Family", Head Of Department, Doctor Of Philosophy, Tashkent, Uzbekistan

Beknazarova Saida Safibullaevna

Doctor Of Technical Science, Prof. Dept. Audiovisual Technologies Of Tashkent University of Information Technologies Named By Muhammad Al- Khwarizmi, Tashkent, Uzbekistan

\title{
ABSTRACT
}

In this article, we will talk about the various principles of conflict resolution, which serve the development of social, economic, interpersonal relations in modern societies and are widely used in all forms of social system (family, economy, production, labor market, state administrative practice), democratic principles that ensure the protection of human rights and freedoms, the introduction of conflict resolution methods into the practice of the neighborhood, the problems of personal development through effective eradication of crises have been investigated.

\section{KEYWORDS}

Compensation, dispute, mediation, dispute management, alternative methods, mediation.

\section{INTRODUCTION}

The development of the Family Institute in our country is defined as one of the priorities of social policy. The idea of" healthy family healthy society", as well as carrying out 
scientific research aimed at solving such problems as the wide promotion of the constitutional print-up" family in the protection of society and the state", the development of family values, the profile of negative social situations in the family, the Prevention of family conflicts, the development of the necessary knowledge, skills and professional

It should be said that" alternative dispute resolution " is a general concept and it is used in relation to many formal and nonformal methods other than traditional court practice. Venda Suzuki, Christophe Besemer, Liza Parkinson, Djon foldjer studies investigated the factors of personality harmonious development, alternative mediation, conflict management in social life, the problems of personal development through effective elimination of crises.

In modern societies, the mediation is an advanced and alternative way of solving various conflicts in life through peace, negotiation and reconciliation, which serves the development of social, economic, individual relations and is widely used in all forms of social system - family, economy, production, labor market, state administrative practice. About its modern species and forms are mentioned below.

Problem-solving (focused on solving problems). This is emphasized not by the position of the parties, but by their interest. The mediation first allows the parties to explain their positions, and then it means that the parties have common interests and needs. Business mediation. It is aimed at resolving disputes in the sphere of production, entrepreneurial activity, between economic entities, in the sphere of business.
Family mediation. The individual in the family is a type of mediation aimed at resolving conflicts and maintaining normal relations with children, family members.

Mediation for corporate or labor disputes. It is aimed at the solution of labor disputes between the employer and the employee arising from Labor Relations.

Judicial mediation. The focus is on the solution of judicial disputes between the defendant and the victim, the plaintiff. World practice shows that this type of mediation is $85 \%$ successful.

Mediation. The process of mediation, which takes place with the participation of two or more mediation. In Co-mediation, psychologists, lawyers can participate.

Transformative mediation. A strong discussion between the sides of the Bond takes place with the minimum participation of the mediation. The purpose of this is to help the parties involved in the dispute better understand each other and understand their needs.

Narrative mediation. In the narrative approach, the mediation works not on the basis of the previously planned plan, but on the reaction of the parties, deconstructs the controversial situation and constructs an alternative option based on the interests of the parties.

Restorative mediation. Mediation is a method of resolving a dispute between people by restoring their ability to understand each other and come to a consensus on a controversial situation.

Evaluation mediation (evaluative approach). Mediation aimed at assessing the situation. 
Mediation offers her various solutions by evaluating the situation.

Therapeutic mediation is aimed at restoring friendly relations and communication skills of the parties.

Chelnok mediation (Shatl-mediation). The mediation will negotiate alternately with the parties.

There are also models of Steele, Christophe Besemer.

Narrative and transformative models are used mainly in family mediation in cases where one of the parties has not made a decision and hopes to restore the relationship. The narrative model of mediation is conducted in the form of a conversation, in which the parties tell about the history of their relationship. Its main techniques are ecsternalization (the separation of the history of the confluence from the personality of the parties and its perception as an external problem), deconstruction of the history of the confluence (the separation of the Fakt from the interpretations), refraining (the transformation of the assessment of the situation into a positive one), finding "unique episodes", that is, the awakening of the desire to restore.

Supporters of the facetive approach and transformative model berock Bush and Joseph Foldjers believe that the social significance of mediation is to change the relationship between people qualitatively on the positive side and restore the relationship. The main purpose of this model is to load responsibility on the parties on the issue in the middle, the success of the mediation is also assessed by the steps taken by the parties to reach an agreement on the confluence and to understand each other. In the role of mediation fasilitator, it is necessary to regularly examine the parties and determine their readiness for negotiations. The main goal of the mediation is the organization of the process of communication between the parties (hearing each other) and mutual recognition (views), consisting of fascination. As a result of this, mutual understanding of the parties, positive changes occur.

Family mediation. The family is a sacred spiritual abode, in which the spirituality, world outlook, personality, temperament and nature are formed. The family serves as the foundation of such high concepts as the first vital outlines, moral criteria about good and evil, faith, compassion, or-shame, nobility, love, responsibility, patriotism, humanism, enlightenment, patience, diligence. Family inheritance from ancestors is a powerful educational factor that supplies the heritage values, sharqana manners, sacred traditions from our ancestors to later generations, such as national values that have been preserved for centuries, respect for adults, keeping manners before them, receiving prayers, nobility to the little ones.

Family and family relations play a key role in the emergence and development of social relations in the life of society.

Any society and civilizations were formed and developed around family social relations. The prosperity of the state and society as a whole and at the same time the crisis also directly depends on the state of family relations. Ensuring the stability of family and family relations is one of the main areas of national security as a strategic interest of any state. 
Unfortunately, in recent times, under the influence of globalism, the collection of civilizations, economic, social, ideological, moral-moral factors, family values remain in danger. By the end of 2019, the status of the annulment of marriages concluded in some Western countries is estimated to be from $40 \%$ to $67 \%$, which is considered a serious threat to the crisis and social security of the family institution.

Unfortunately, even in the countries of the Central Asian region, where family relations are traditionally strong, the number of divorces is increasing. In our country, too, there is concern that the number of divorces is increasing, despite the implementation of regular measures to prevent family divorces. Given the increase in family conflicts, the increasing number of divorces and the serious social consequences, modern societies pay special attention to their prevention and constructive solution.

In this regard, many states have tried to develop family mediation as an effective method of family conflict resolution.

Family mediation has emerged as a necessity of peaceful settlement of family disputes, prevention of divorce, resolution of problems arising in the family and the importance of ensuring family stability. Family mediation is the most common type of mediation and is recognized as the most effective way to resolve all types of family conflicts and disagreements. The concept of family mediation is used in solving family disputes (conflict, conflict, disagreement) between the parties to the dispute (couple, children, relatives).
Family mediation as a social phenomenon arises from the understanding that the laws and the court can't effectively resolve the conflict between family members, because at the core of any legal dispute lies personal disputes, the principles of morality and cooperation for its elimination are more appropriate than pressure and judgment. People can execute a court judgment, but they can't be forced to forgive or reconcile. The resolution of the dispute depends on mutual respect, understanding, recognition of each other, respect for the desires and interests of the parties. When we say family relations, all relations in the family (relations between the couple, parents and their children, relatives, etc.) is understood. Despite the variety of family relations, they have common features:

- Strong emotional connection between the parties;

- Intending not to confuse individuals with family conflicts;

- Deep personal experiences;

- High emotional conflict abuse;

- The impact of conflict consequences on

- The personal life of participants, especially children.

Family mediation covers many of the following issues related to family life, with its help it is possible to achieve the resolution of most of the conflicts that arise in family relations:

- Disputes between the couple (the conclusion of a marriage contract, the dissolution of marriage, the conflict of worldview, the definition of paternity, the 
adoption of a child, guardianship, the payment of alimony, the care of parents, elderly relatives, the right to inheritance, etc.);

- Disputes between parents and children (deprivation of parental rights,);

- Conflicts between close relatives (brothers, sisters, relatives.

The researchers emphasize that in family conflicts, the parties are not prepared for a calm and rational approach, given their strong passions, in a state of deep depression and psychological crisis, appropriate experience, qualification from the mediation is required. Of great importance is the special knowledge and competence of the mediation, knowledge of communicative techniques, professionalism.

It is known that the first Reconciliation Services on Family Matters appeared in 1939 year in the US State of California. Since the middle of the twentieth century, the demand for alternative dispute resolution in the US has sharply increased. According to the researchers, during this period, due to the growth of social disputes, the number of appeals to the courts has increased dramatically, and in the pre-trial period, the need for the establishment of new institutions for dispute resolution has arisen.

The theory of the disputable nature of man was put forward by the American sociologist, psychologist Morton Doych, and the technology of rational use of a third party in dispute resolution was proposed.

The first private mediation service was founded in 1974 year in Atlanta, USA by advokat and family consultant jim Kugler (Coogler). The practice of using third-party, that is, intermediationries ' assistance in dispute resolution has become popular in Kugler's 1978 book titled "structured Mediationtion in Divorce Settlement". In 1975, Kugler founded the Family Mediation Association.

In the practice of foreign countries, Family Mediation is used to regulate disputes arising in the annulment of marriage, to determine the place of residence of children after divorce, to establish the procedure for communicating with the child, to participate in the upbringing of children by parents living separately, to determine the amount of alimony, to be a common property and other issues.

According to Lisa Parkinson, a UK researcher who has conducted major research in the field of Family Mediation, Family Mediation has been used in relation to divorce or marriage termination cases, helping the parties maintain parental status and fulfill their obligations. Therefore, in the US, the concept of" mediation in divorce " was formed. In modern literature, the concept of" family mediation " is widely used not only for disagreements between divorced parties, but also for solving a number of issues that arise during the formalization of family relations, the conclusion of a marriage contract or a joint prison.

In the technological segment, there are models of narratives, ecosystems, transformative, provocative, restorative, in which the effectiveness of family mediation, in contrast to classical mediation, is recognized.

The classical model of mediation is based mainly on the theory of assistance to the parties in the organization of negotiations, 
and the mediation's mission is to bring the parties to a mutually beneficial agreement. But in disputes over divorce, the parties are not ready to negotiate on the basis of calm, rational thinking, and are given strong passions, in a state of deep depression and mental crisis. As a result of this, the above models of the mediation began to appear.

The provocative model provides for the opportunity to work with families who are in a deep escalation phase of the dispute, almost without the possibility of a solution with the help of mediation, and who are recommended to use judicial assistance. In this method, initially the parties are taken to the highest stage of the conflict, and then, through metaphors, stories, the state of war is shifted from peace to peace.

The ecosystem model is effective in eliminating conflicts associated with the upbringing of children and is aimed at developing long-term arrangements that are in the interests of the family as a holistic system. The main goal of the mediation is to develop a wide-coverage scheme of the family, taking into account the interests of the ecodastor, that is, members of the family and children.

Technologically, Family Mediation uses techniques such as special communicative theories, including empathy, psychological help, counseling, and family therapy.

As an independent regulation of family mediation issues on an international scale, the Council of Europe's Recommendation No. 98 on "mediation in family disputes" may be cited. These recommendations reflect the principle of ensuring the interests of children in the process of divorce. In principle, parents divorced by the mediation are reminded that special attention should be paid to the interests of children and care should be taken for the future of children.

Today, in the national legislation of many states, the technology of mediation in the regulation of family disputes is defined as compulsory practice by the courts. In particular, in countries such as Australia, the United States, Great Britain, Germany, Canada, France, Bulgaria, there is a legal practice of binding the mediation in the regulation of family relations.

In the law "on family", adopted in 1996 in the UK, lawyer is defined as compulsory to send clients who have applied for legal assistance in family disputes to the mediation to pass the initial information evaluation stage known as Mediation Information and Assessment Meetings. Employees of the social sphere, family consultants, family psychologists, psychiatrists are involved in family mediation.

In the US, mediations are mainly representatives of the social sphere, subordinate to the chairman of the family court. Only lawyers are involved in the process in matters that are legally complex (obtaining alimony, becoming common property).

In legal practice, Co-Mediation has developed as a specific direction of family mediation. In it, the mediation is conducted by two mediations, and one of them is determined to be a psychologist, a psychotherapist, and the other to be a lawyer (lawyer, notary). There is also a wide range of procedures for adhering to gender equality when taking co-mediations. Financial aspects of family mediation are also notable. 
In particular, in Austria, state-funded mediation expenditures are applied to family mediation. In Austria, the national scale of expenses is established when paying for services in the field of family mediation. In Austria the activities of the family relations centers are financed from the federal budget. Financial support is provided by the state to public organizations such as family Relationship Centers. In the UK, the first sessions of the mediation under the courts are considered free of charge. If the parties do not reach an agreement in the initial stages, the costs of the next stages will be covered by them. At the same time, today, the use of the services of private mediations in the regulation of family relations is widespread in practice.

Thus, the mediation is a modern means of creating favorable conditions for the peaceful and sustainable settlement of disputes, taking into account the time, financial, emotional resources, sentiments and values. The importance of this institution in the organization of the reduction of wages, taking into account the full interests of the parties, especially children, is becoming relevant.

The use of mediation powers in the implementation of its powers by civil servants and citizens, in legal relations, in resolving disputes within the framework of state structures, in the sphere of pre-judicial socialLabor, family, corporate-business, serves to establish effective communication in civil society, to increase the legitimacy and reliability of the activities of state bodies.

In particular, the skills and knowledge of effective resolution of social conflicts and controversial situations in the neighborhood and family system, negotiation competent are of great importance in the organization of a wide range of activities with the neighborhood and families.

\section{REFERENCES}

1. Law of the Republic of Uzbekistan "on Media". T. 2019 y.

2. Decree of the president of the Republic of Uzbekistan on measures to ensure more effective organization of the process of acquisition of rights over land parcels and other immovable property as part of the South Caucasus pipeline expansion project more ... T. $2020 \mathrm{y}$.

3. Harold Abramson. Support of the parties in the mediation procedure. Moscow: ICUPC, 2013 - -560 p.

4. Christoph Besemer. Mediation. Mediation in conflicts. Kaluga: Spiritual Knowledge, 2004. -179 p.

5. Lisa Parkinson. Family mediation. 2nd ed., Moscow: ICUPC, 2016.

6. Bush R., Folger J. What mediation can do. A transformative approach to conflict. Kiev: Publisher Zakharenko V. A., 2007. $264 \mathrm{p}$.

7. Hertel, Anita von. Professional conflict resolution: Mediation competence in your life. - St. Petersburg: Werner Regen Publishing House, 2007. - 272 p.

8. Roger Fisher, William Ury. Getting to Yes: Negotiating Agreement Without Giving In. 1981, 1988. Fischer R., Urey W. The path to agreement, or negotiations without defeat. Translated from English: A. Gorelova; Preface: V. A. Kremenyuk. - M., 1992. // Electronic publication: Center for Humanitarian Technologies. 
10.02.2012.

https://www.norma.uz/raznoe/evrope yskiy_kodeks_povedeniya_mediationo v_izvlecheniya you know what?

9. https://aussiedlerbote.de/2020/07/vgermanii-26-tysyach-par-razvelis-posle25-let-braka/.

10. https://www.law.cornell.edu/wex/alter native_dispute_resolution you know what? 